\title{
Synthesis of new 3-(2-mercapto-4-oxo-4H-quinazolin-3-yl)- benzenesulfonamides with strong inhibition properties against the tumor associated carbonic anhydrases IX and XII
}

\author{
Murat Bozdag a,d, Ahmed Mahmoud Alafeefy ${ }^{\mathrm{b}}$, Abdul Malik Altamimi ${ }^{\mathrm{c}}$, Fabrizio Carta ${ }^{\mathrm{a}}$, \\ Claudiu T. Supuran ${ }^{\mathrm{a}, *}$, Daniela Vullo ${ }^{\mathrm{d}, *}$ \\ ${ }^{a}$ Università degli Studi di Firenze, Dipartimento Neurofarba, Sezione di Scienze Farmaceutiche, Polo Scientifico, Via U. Schiff 6, 50019 Sesto Fiorentino, Florence, Italy \\ ${ }^{\mathrm{b}}$ Chemistry Department, Kulliyyah of Science, International Islamic University, Kuantan, Malaysia \\ c Pharmaceutical Chemistry Dept., College of Pharmacy, Prince Sattam Bin Abdulaziz University, Saudi Arabia \\ ${ }^{\mathrm{d}}$ Università degli Studi di Firenze, Dipartimento di Chimica, Laboratorio di Chimica Bioinorganica, Rm. 188, Via della Lastruccia 3, 50019 Sesto Fiorentino (Florence), Italy
}

\section{A R T I C L E I N F O}

\section{Article history:}

Received 3 March 2017

Revised 21 March 2017

Accepted 24 March 2017

Available online 29 March 2017

\section{Keywords:}

Carbonic anhydrase inhibitors (CAIs)

Quinazolines

Tumors

Imaging

\begin{abstract}
A B S T R A C T
We report a series of novel metanilamide-based derivatives 3a-q bearing the 2-mercapto-4-oxo- $4 \mathrm{H}$ quinazolin-3-yl moiety as tail. All compounds were synthesized by means of straightforward condensation procedures and were investigated in vitro for their inhibition potency against the human $(h)$ carbonic anhydrase (CA; EC 4.2.1.1.1) isoforms I, II, IX and XII. Among all compounds tested the 6-iodo 3g and the 7-fluoro $3 \mathbf{i}$ derivatives were the most potent inhibitors against the tumor associated CA IX and XII isoform $\left(\mathrm{K}_{\mathrm{I}} \mathrm{S} 1.5\right.$ and $2.7 \mathrm{nM}$ respectively for the $h$ CA IX and $\mathrm{K}_{\mathrm{I}} \mathrm{S} 0.57$ and $1.9 \mathrm{nM}$ respectively for the $h \mathrm{CA}$ XII).

The kinetic data reported here strongly support compounds of this type for their future development as radiotracers in tumor pathologies which are strictly dependent on the enzymatic activity of the $h$ CA IX and XII isoforms.
\end{abstract}

(c) 2017 Elsevier Ltd. All rights reserved.

\section{Introduction}

The carbonic anhydrase (CAs, EC 4.2.1.1) IX is a validated pharmacological target for the treatment of hypoxic tumors. ${ }^{1}$ To date the hCA IX monoclonal chimeric antibody Girentuximab $\left(\right.$ Rencarex $^{\circledR}$ ) and its iodo radiolabeled derivative (Redectane ${ }^{\circledR}$ ) are currently marketed for the treatment and diagnosis of renal cell carcinomas (RCCs) respectively. Among the small molecule drugs, the most advanced product in the pipeline is represented by the sulfanilamide derivative SLC-0111 (Fig. 1) discovered by our group, which successfully ended its Phase-I trial program. ${ }^{2}$

Despite the availability of antibody-based drugs, the development of small molecules as $h$ CA IX selective inhibitors, such as the SLC-0111, still remains an attractive approach for two main reasons: $i$ ) small molecule drugs do not suffer of the heavy drawbacks usually associated to the antibodies such as immunogenicity, ${ }^{3}$ long circulation times in the bloodstream, ${ }^{4}$ and low penetration into solid tumors; ${ }^{5}$ ii) production costs of clinical grade antibodies are quite high when compared to "classical" chemical drugs. $^{6}$

\footnotetext{
* Corresponding authors.

E-mail addresses: claudiu.supuran@unifi.it (C.T. Supuran), daniela.vullo@unifi.it (D. Vullo).
}

Several classes of compound moieties have been investigated with the final intent to identify hCA IX selective and druggable small molecules. The main contributions include phenols and thiophenols, ${ }^{7,8}$ polyamines, ${ }^{9}$ cyclic and/or fluorinated tertiary sulfonamides, ${ }^{10}$ dithio/monothiocarbamates and xanthates, ${ }^{11,12}$ as well as the coumarins and their thio derivatives. ${ }^{13-18}$ However, the primary sulfonamides $\left(-\mathrm{SO}_{2} \mathrm{NH}_{2}\right)$ still represent the main class of CA inhibitors (CAIs) investigated so far. They strongly coordinate the enzymatic metal ion $\left(\mathrm{Zn}^{2+}\right.$ in the humans), which is buried at the low edge of the conical active site, ${ }^{19}$ whereas the tail of the molecular scaffold is subjected to derivatizations with various chemical moieties. Such a strategy, commonly referred as the tail approach, resulted particularly efficient in the obtainment of isoform selective CAIs of the sulfonamide $\left(-\mathrm{SO}_{2} \mathrm{NH}_{2}\right)$ type, ${ }^{20}$ but also coumarin, ${ }^{21}$ sulfocoumarin $^{22}$ as well as dithiocarbamate derivatives ${ }^{23}$ were obtained. From the molecular viewpoint the isoform selectivity of small molecules through the tail approach resides in the modulation of the number/type of chemical interactions interceding between the enzymatic rim of the targeted CA, highly variable, and the tail end of the inhibitor. ${ }^{19 c, 20}$ Thus we considered that the 2-mercapto-4-oxo-4H-quinazolin-3-yl scaffold is of particular relevance in this context, since it offers multiple sites for hydrogen bonding interactions, and the additional substitutions 
<smiles>NS(=O)(=O)c1ccc(NC(=O)Nc2ccc(F)cc2)cc1</smiles>

\section{SLC-0111}

Fig. 1. Chemical structure of the SLC-0111 carbonic anhydrase IX inhibitor.<smiles>[R]Cc1cccc2nc(S)n(-c3cccc(S(N)(=O)=O)c3)c(=O)c12</smiles>

Fig. 2. Interaction sites offered by the 2-mercapto-4-oxo-4H-quinazolin-3-yl scaffold.

within the scaffolds may serve for further enhancing the ligandenzyme complex (Fig. 2).

Herein, as extension of our recent previous reports ${ }^{24-26}$ and with the aim to identify selective $h$ CA IX drug leads, we report a series of sulfonamide compounds possessing the 3-(2-mercapto4-oxo-4H-quinazolin-3-yl)-moiety and we explored their inhibitory effects against the four physiological relevant $h C A$ isoforms such as the cytosolic and abundantly expressed I, II and the tumor associated IX and XII.

\section{Results and discussion}

\subsection{Chemistry}

All compounds reported here, $\mathbf{3 a}-\mathbf{q}$, were obtained by using the same synthetic strategy developed from our groups for the obtainment of 2-mercapto-4-oxo-4H-quinazolin-3-yl scaffolds substituted at the 3 position with ethylaminobenzene sulfonamides ${ }^{24}$ or sulfanilamides. ${ }^{25}$ Specifically for this work we coupled the commercially available anthranilic acids $\mathbf{1 a - q}$ with the freshly synthesized 3-isothiocyanato-benzenesulfonamide $\mathbf{2}$ in alcohol at reflux (Scheme 1).
All new compounds reported here were properly characterized by means of NMR, MS and elemental analyses.

\subsection{Carbonic anhydrase inhibition}

All synthesized compounds $\mathbf{3 a}-\mathbf{q}$ were investigated for their inhibition potencies against the four physiological relevant $h C A s$ I, II, IX and XII, by means of the stopped flow $\mathrm{CO}_{2}$ hydrase assay, ${ }^{27}$ and their data compared to the standard CAI acetazolamide (AAZ).

Overall the compounds $\mathbf{3 a}-\mathbf{q}$ reported showed interesting inhibitory activities. A structure-activity-relationship (SAR) is below reported.

i) The cytosolic and abundantly expressed $h \mathrm{CA}$ I was the least inhibited isoform among those considered in this study with $\mathrm{K}_{\mathrm{I}}$ values, reported in Table 1, spanning from 135 to $7650 \mathrm{nM}$. In general 3a and its halogen substituted derivatives $\mathbf{3 b}-\mathbf{i}$ showed higher inhibition potencies when compared to the alkyl and alkoxy containing counterparts $\mathbf{3 j}-\mathbf{q}$ and in the same order of magnitude of the $\mathbf{A A Z}$ (Table 1 ). Among the first series, the nature of the halide as well as its position within the 2-mercapto-4-oxo-4H-quinazolin scaffold strongly affected the $h$ CA I inhibition values. For instance the 7-chloro derivative $3 \mathbf{c}$ was 1.7 and 2.1 times stronger than its 6 - and 8-chloro-substituted regioisomers respectively. The 8-bromo derivative 3f was more potent than its 7-bromo derivative $3 \mathbf{e}$ (2.1-fold). Conversely when the fluorine atom was considered, the 6-substituted regioisomer $\mathbf{3 h}$ showed higher inhibition potency when compared to its 7-fluoro counterpart $3 \mathbf{i}\left(\mathrm{K}_{\mathrm{I}} \mathrm{S}\right.$ of 135 and $169 \mathrm{nM}$ respectively). The bulky 6-iodo-2-mercapto-4-oxo-4H-quinazolin derivative $\mathbf{3 g}$ was the least potent among the halogen containing compounds in inhibiting the $h$ CA I isoform ( $\left.\mathrm{K}_{\mathrm{I}} 387 \mathrm{nM}\right)$.

As above stated the introduction in $\mathbf{3 a}$ of alkyl moieties resulted detrimental for the inhibition potency. The 6-methyl derivative $\mathbf{3 j}$ was the most potent in this series in inhibiting the $h$ CA I isoform $\left(\mathrm{K}_{\mathrm{I}} 563 \mathrm{nM}\right)$, followed by the 8methyl regioisomer 3k which resulted 1.3 times less potent. All remaining compounds showed remarkably higher $\mathrm{K}_{\mathrm{I}}$ values which were all in the $\mu \mathrm{M}$ range (Table 1 ).

ii) In analogy to the $h$ CA I, also the cytosolic CA II isoform was efficiently inhibited from the unsubstituted 3a $\left(\mathrm{K}_{\mathrm{I}} 14.6 \mathrm{nM}\right)$<smiles>[R]c1ccc(C(=O)O)c(N)c1</smiles>

Scheme 1. General synthetic scheme for the obtainment of compounds 3a-q. 
Table 1

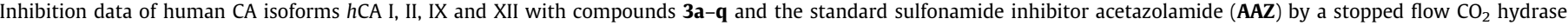
assay. $^{27}$

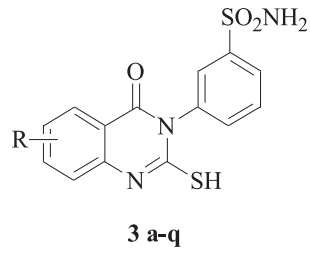

\begin{tabular}{|c|c|c|c|c|c|}
\hline \multirow[t]{2}{*}{ Compound } & \multirow[t]{2}{*}{$\mathrm{R}$} & \multicolumn{4}{|c|}{$\mathrm{K}_{\mathrm{I}}(\mathrm{nM})^{*}$} \\
\hline & & $h \mathrm{CAI}$ & $h$ CA II & $h$ CA IX & $h$ CA XII \\
\hline $3 \mathbf{a}$ & $\mathrm{H}$ & 189 & 14.6 & 76.1 & 10.5 \\
\hline 3b & $6-\mathrm{Cl}$ & 276 & 19.8 & 45.1 & 12.0 \\
\hline $3 c$ & 7-Cl & 164 & 0.98 & 15.4 & 5.8 \\
\hline 3d & $8-\mathrm{Cl}$ & 348 & 10.7 & 9.5 & 3.5 \\
\hline $3 e$ & $7-\mathrm{Br}$ & 296 & 1.1 & 16.8 & 2.4 \\
\hline $3 f$ & $8-\mathrm{Br}$ & 143 & 0.82 & 4.0 & 2.6 \\
\hline $3 g$ & 6-I & 387 & 27.6 & 1.5 & 0.57 \\
\hline $3 \mathbf{h}$ & $6-F$ & 135 & 7.0 & 4.4 & 3.2 \\
\hline $3 \mathbf{i}$ & $7-F$ & 169 & 6.6 & 2.7 & 1.9 \\
\hline $3 \mathbf{j}$ & 6-Me & 563 & 18.6 & 58.9 & 45.2 \\
\hline $3 k$ & 8-Me & 719 & 65.4 & 25.2 & 7.6 \\
\hline 31 & $6,7-(\mathrm{Me})_{2}$ & 1650 & 210 & 34.5 & 9.8 \\
\hline $3 \mathrm{~m}$ & $6-\mathrm{MeO}$ & 3200 & 98.4 & 13.0 & 10.5 \\
\hline $3 n$ & 7-MeO & 7650 & 104 & 25.0 & 23.4 \\
\hline 30 & 8-MeO & 965 & 77.8 & 15.6 & 23.9 \\
\hline $3 \mathbf{p}$ & $6,7-(\mathrm{MeO})_{2}$ & 3570 & 126 & 19.8 & 4.7 \\
\hline $3 q$ & $6,7,8-(\mathrm{MeO})_{3}$ & 4600 & 76.5 & 20.1 & 6.0 \\
\hline $\mathrm{AAZ}$ & - & 250 & 12.0 & 25.0 & 5.7 \\
\hline
\end{tabular}

* Mean from 3 different assays, by a stopped flow technique (errors were in the range of $\pm 5-10 \%$ of the reported values).

and from its halogen derivatives $\mathbf{3 b}-\mathbf{i}\left(\mathrm{K}_{\mathrm{I}} \mathrm{s}\right.$ between 27.6 and $0.82 \mathrm{nM})$. Among the halogen containing series a similar enzymatic profile to the $h$ CA I is also shown. Thus the 7chlorosubstituted 2-mercapto-4-oxo-4H-quinazolin scaffold 3c $\left(\mathrm{K}_{\mathrm{I}} 0.98 \mathrm{nM}\right)$ was by far more potent in inhibiting the $h \mathrm{CA}$ II than its 6- and 8-regioisomers ( $\mathrm{K}_{\mathrm{I}} \mathrm{S} 19.8$ and $10.7 \mathrm{nM}$ respectively), and again the 8 -bromo derivative 3 f was slightly more potent when compared to its 7-substituted regioisomer ( $\mathrm{K}_{\mathrm{I}} \mathrm{S} 0.82$ and $1.1 \mathrm{nM}$ respectively). The bulky iodo derivative $\mathbf{3 g}$ was confirmed as the weaker inhibitor among the halogen containing compounds and even less potent when compared to the standard CAI AAZ (Table 1). In the case of the fluoro substituted derivatives $\mathbf{3 h}$ and $\mathbf{3 i}$ it is worth noticing that their inhibition profiles against the $h$ CA II isoform was opposite when compared to the $h C A$ I. In fact the 7-fluoroderivative was slightly more potent (0.9-fold) than its 6-substituted regioisomer. Finally as for the $h$ CA I, the alkyl containing derivatives showed weak $\mathrm{K}_{\mathrm{I}}$ data, with the 6-and 8-methyl substituted compounds $\mathbf{3 j}$ and 3k being the strongest in the series $\left(\mathrm{K}_{\mathrm{I}} \mathrm{S}\right.$ of 18.6 and $65.4 \mathrm{nM}$ respectively).

iii) An interesting enzymatic profile was shown for the transmembrane and tumor associated $h \mathrm{CA}$ IX. The unsubstituted 3a was the least potent within all the series reported $\left(\mathrm{K}_{\mathrm{I}}\right.$ $76.1 \mathrm{nM}$ ) and far less active when compared to the standard CAI AAZ ( $\left.\mathrm{K}_{\mathrm{I}} 25 \mathrm{nM}\right)$. The introduction of a chloro moiety within the 2-mercapto-4-oxo-4H-quinazolin scaffold to afford the regioisomers $\mathbf{3 b}$-d, determined a remarkable increase of the inhibition potency. As shown in Table 1, the 8 -substituted derivative 3d was the most potent among the series with a $\mathrm{K}_{\mathrm{I}}$ value of $9.5 \mathrm{nM}$ and thus 4.7 and 1.6 times more effective than $\mathbf{3 b}$ and $\mathbf{3 c}$ respectively. In analogy to the cytosolic hCA I and II, also for the IX isoform the in vitro inhibition profiles of the 7-and 8-bromosubstituted derivatives 3e and 3f were similar ( $\mathrm{K}_{\mathrm{I}} \mathrm{S} 16.8$ and $4.0 \mathrm{nM}$ respectively). It is noteworthy that in this case their selectivity index $\left(\mathrm{K}_{\mathrm{I}} \mathbf{3 f} / \mathrm{K}_{\mathrm{I}} \mathbf{3 e}\right)$ for the $h$ CA IX isoform is the highest reported, including the $h C A$ XII discussed later. The fluoro containing derivatives $\mathbf{3 h}$ and $\mathbf{3 i}$ showed low nanomolar inhibition potencies against the $h C A$ IX and no particular differences between the two regioisomers were reported $\left(\mathrm{K}_{\mathrm{I}} \mathrm{S}\right.$ 4.4 and $2.7 \mathrm{nM}$ respectively). Interestingly the iodo derivative $3 g$ showed a remarkable inhibition potency $\left(K_{I}\right.$ $1.5 \mathrm{nM}$ ), which makes it as the most potent inhibitor against the IX isoform among all the compound series here reported. As for the alkyl and alkoxy substituted derivatives $\mathbf{3 j}-\mathbf{q}$, the 6 -methyl regioisomer $\mathbf{3} \mathbf{j}$ was the least effective in inhibiting the hCA IX ( $\left.\mathrm{K}_{\mathrm{I}} 58.9 \mathrm{nM}\right)$, followed by its doubling 31 ( $\mathrm{K}_{\mathrm{I}}$ $34.5 \mathrm{nM}$ ) and by its 8-substituted derivative 3k which showed a $\mathrm{K}_{\mathrm{I}}$ value almost identical to the standard CAI AAZ (25.2 nM and $25.0 \mathrm{nM}$ respectively). Better results were obtained when the methoxy moieties were introduced as in compounds 3m-q. Among the monosubstituted methoxy derivatives, the 6 - and the 8-regioisomers were the most effective ( $\mathrm{K}_{\mathrm{I}} \mathrm{S} 13.0$ and $15.6 \mathrm{nM}$ respectively), whereas the 7 -methoxy $3 n$ was the weakest (25.0 nM). Further introduction of methoxy moieties to afford the di- or tri-substituted compounds 3p and 3q didn't result in any significant effect on the kinetic data ( $K_{\mathrm{I}} 19.8$ and $20.1 \mathrm{nM}$ respectively).

iv) The second tumor associated $h C A$, the XII isoform, resulted strongly inhibited from all the compounds reported. The only exception was represented from the 6-methylsubstituted derivative $\mathbf{3 j}$ which showed a $K_{\mathrm{I}}$ value of $45.2 \mathrm{nM}$ (Table 1). The introduction within $3 a\left(K_{I} 10.5 \mathrm{nM}\right)$ of the chloro moiety at 6-, 7- and 8-position to afford $\mathbf{3 b} \mathbf{b}-\mathbf{d}$, resulted in a progressive increase of the inhibition potency ( $\mathrm{K}_{\mathrm{I}} \mathrm{S} 12.0,5.8$ and $3.5 \mathrm{nM}$ ). The bromo regioisomers $\mathbf{3 e}$ and 3f resulted nearly equal for their ability to inhibit the $h \mathrm{CA}$ 
IX isoform ( $\mathrm{K}_{\mathrm{I}} \mathrm{S} 2.4$ and $2.6 \mathrm{nM}$ respectively), whereas among the fluoro derivatives, the 7-substituted isomer $\mathbf{3 i}$ showed a preferential inhibition over its 6-fluoro regioisomer $\mathbf{3 h}$ ( $\mathrm{K}_{\mathrm{I}} \mathrm{S} 1.9$ and $3.2 \mathrm{nM}$ respectively). As for the $h$ CA IX, also the XII isoform resulted strongly inhibited from the iodo derivative $\mathbf{3 g}$, which was the strongest among all the compound series reported $\left(\mathrm{K}_{\mathrm{I}} 0.57 \mathrm{nM}\right)$. As above stated, the 6-methyl compound $\mathbf{3 j}$ was the weakest, among all compounds reported, in inhibiting the $h$ CA XII $\left(\mathrm{K}_{\mathrm{I}} 45.2 \mathrm{nM}\right)$. It is interesting to note that the 8-methyl regioisomer $3 \mathbf{k}\left(\mathrm{K}_{\mathrm{I}}\right.$ $7.6 \mathrm{nM})$ and the 6,7-dimethyl derivative 31 ( $\left.\mathrm{K}_{\mathrm{I}} 9.8 \mathrm{nM}\right)$ resulted 5.9 and 4.6 times respectively more potent against this isoform. A significant influence of the regioselectivity on the hCA XII inhibition data was also evident for the methoxy substituted derivatives $\mathbf{3 m}$-o. In this case the 7- and the 8-methoxy compounds $\mathbf{3 n}$ and $\mathbf{3 o}$ were 2.2. and 2.3 times respectively less potent when compared to the 6-methoxy isomer $3 \mathrm{~m}\left(\mathrm{~K}_{\mathrm{I}} 10.5 \mathrm{nM}\right)$. Finally the multiple introduction of methoxy groups within the 2-mercapto-4oxo-4H-quinazolin-3-yl scaffold, as for $\mathbf{3 p}$ and $\mathbf{3 q}$, resulted beneficial for the inhibition potency against the hCA XII, as they showed $\mathrm{K}_{\mathrm{I}}$ values comparable to the standard CAI AAZ (see Table 1).

\section{Conclusions}

We reported a series of new metanilamides bearing the 2-mercapto-4-oxo-4H-quinazolin-3-yl as tails. All compounds were obtained by means of condensation of the freshly prepared 3isothiocyanatobenzene sulfonamide $\mathbf{2}$ with commercially available anthranilic acids. All compounds were investigated in vitro for their ability to inhibit the most physiological relevant $h C A$ isoforms such as the cytosolic hCA I, II and the tumor associated IX and XII isoforms. In general all halogen containing compounds $\mathbf{3 b} \mathbf{b} \mathbf{i}$ showed higher inhibition potencies against all the hCA isoforms considered when compared to the unsubstituted $\mathbf{3 a}$ as well as to the alkyl bearing derivatives $\mathbf{3 j}-\mathbf{q}$. The $h$ CA I was the least inhibited isoform, whereas the $h$ CA II, which is deeply involved in glaucoma, is effectively inhibited from the 7-chloro 3c, 7- and 8-bromo derivatives $3 e$ and $3 \mathbf{f}$ respectively $\left(K_{\mathrm{I}} \mathrm{S} 0.98,1.1\right.$ and $\left.0.82 \mathrm{nM}\right)$. As for the tumor associated $h$ CA IX isoform, the 6 -iodo $\mathbf{3 g}$ and the 7-fluoro $3 \mathbf{i}$ derivatives resulted the most potent inhibitors among all compounds tested ( $\mathrm{K}_{\mathrm{I}} \mathrm{S} 1.5$ and $2.7 \mathrm{nM}$ respectively). Such result is of particular interest, since the presence of fluorine and iodine makes them attractive leads for their possible development as radiotracers for diagnostic purposes in hypoxic tumors positively expressing the $h$ CA IX isoform. In analogy to the $h$ CA IX, also the XII isoform resulted potently inhibited from $\mathbf{3 g}$ and $\mathbf{3 i}\left(\mathrm{K}_{\mathrm{I}} \mathrm{s} 0.57\right.$ and $1.9 \mathrm{nM}$ respectively). In addition the alkyl poly-substituted derivatives $\mathbf{3 p}$ and $\mathbf{3 q}$ resulted also quite effective in inhibiting this isoform with $\mathrm{K}_{\mathrm{I}} \mathrm{S}$ of 4.7 and $6.0 \mathrm{nM}$ and thus comparable to the halogen derivatives $\mathbf{3 b}-\mathbf{i}$.

We conclude that some of these compounds are of particular relevance for their future development of new leads with diagnos- tic applications in pathologies expressing the $h$ CAs IX and XII such as the hypoxic tumors.

\section{Experimental protocols}

\subsection{Chemistry}

Anhydrous solvents and all reagents were purchased from Sigma-Aldrich, Alfa Aesar and TCI. All reactions involving air- or moisture-sensitive compounds were performed under a nitrogen atmosphere using dried glassware and syringes techniques to transfer solutions. Nuclear magnetic resonance $\left({ }^{1} \mathrm{H} N M R,{ }^{13} \mathrm{C}\right.$ NMR) spectra were recorded using a Bruker Avance III $400 \mathrm{MHz}$ spectrometer in DMSO- $d_{6}$. Chemical shifts are reported in parts per million (ppm) and the coupling constants $(J)$ are expressed in Hertz (Hz). Splitting patterns are designated as follows: s, singlet; $\mathrm{d}$, doublet; t, triplet; q, quadruplet; m, multiplet; brs, broad singlet; $\mathrm{dd}$, double of doublets. The assignment of exchangeable protons was confirmed by the addition of $\mathrm{D}_{2} \mathrm{O}$. Analytical thin-layer chromatography (TLC) was carried out on Merck silica gel F-254 plates. Flash chromatography purifications were performed on Merck Silica gel 60 (230-400 mesh ASTM) as the stationary phase and ethyl acetate/ $n$-hexane were used as eluents. Melting points (m.p.) were carried out in open capillary tubes and are uncorrected.

\subsubsection{Synthesis of 3-isothiocyanato-benzenesulfonamide $(\mathbf{2})^{28}$}<smiles>Nc1cccc(S(N)(=O)=O)c1</smiles>

Metanilamide

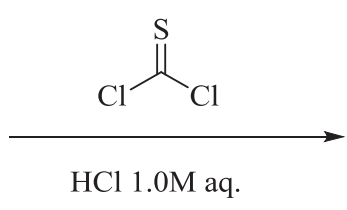

$\mathrm{HCl} 1.0 \mathrm{M}$ aq.<smiles>NS(=O)(=O)c1cccc(N=C=S)c1</smiles>

2
Metanilamide (1.0 eq) was dissolved in a $1.0 \mathrm{M}$ hydrochloric acid aqueous solution and then treated at r.t. with thiophosgene (1.0 eq). A precipitate was readily formed and the reaction mixture was stirred overnight The precipitate formed was collected by filtration, washed with $\mathrm{H}_{2} \mathrm{O}$ and dried under vacuum to afford the titled compounds as white solids, which were used without further purification.

3-Isothiocyanato-benzenesulfonamide 2: $81 \%$ yield; silica gel TLC $R_{f} 0.46(\mathrm{MeOH} / \mathrm{DCM} 10 \% v / v) ; \mathrm{mp} 128^{\circ} \mathrm{C}\left(\right.$ lit. $\left.^{28} 130^{\circ} \mathrm{C}\right) ; \delta_{\mathrm{H}}$ $\left(400 \mathrm{MHz}, \mathrm{DMSO}-d_{6}\right) 7.48\left(2 \mathrm{H}, \mathrm{s}\right.$, exchange with $\left.\mathrm{D}_{2} \mathrm{O}, \mathrm{SO}_{2} \mathrm{NH}_{2}\right)$, $7.63(1 \mathrm{H}, \mathrm{d}, J$ 8.4, Ar-H), 7.68 (1H, dd, $J$ 8.4, Ar-H), $7.89(1 \mathrm{H}, \mathrm{d}, J$ 8.4, Ar-H), $7.92(1 \mathrm{H}, \mathrm{s}, \mathrm{Ar}-\mathrm{H}) ; \delta_{\mathrm{C}}\left(100 \mathrm{MHz}, \mathrm{DMSO}-d_{6}\right)$ 123.0, $124.2,129.7,129.9,130.1(-\mathrm{N}=\mathrm{C}=\mathrm{S}), 132.0,142.0$; Elemental analysis: calc: C 39.24, H 2.82, N 13.07, S 29.93; found: C 39.26, H 2.84, $\mathrm{N} 13.09, \mathrm{~S} 29.91 ; \mathrm{m} / \mathrm{z}$ (ESI positive) $215.00[\mathrm{M}+\mathrm{H}]^{+}$.

4.1.2. General procedure for the synthesis of 3-(2-mercapto-4-oxo-4Hquinazolin-3-yl)-benzenesulfonamides $3 \boldsymbol{a}-\boldsymbol{q}^{24,25}$

EtOH, Reflux<smiles>[R][X]c1ccc2nc(S)n(-c3cccc(S(N)(=O)=O)c3)c(=O)c2c1</smiles> 
The commercially available 2-aminobenzoic acid derivatives 1a-q (1.0 eq) and 2-isothiocyanato-benzenesulfonamide 2 (1.0 eq) were suspended in $\mathrm{EtOH}$ and the reaction mixture was refluxed until starting materials were consumed (TLC monitoring). Then the mixture was cooled down to r.t. and the precipitate formed was collected by filtration to give a residue that was purified by trituration from diethyl ether to afford the desired compounds $3 \mathbf{a}-\mathbf{q}$.

Synthesis of 3-(2-mercapto-4-oxo-4H-quinazolin-3-yl)-benzenesulfonamide (3a). The titled compound $\mathbf{3 a}$ was obtained according to the general procedure previously reported using 2aminobenzoic acid 1a and 2-isothiocyanato-benzenesulfonamide 2. $90 \%$ yield, $\mathrm{mp}<300^{\circ} \mathrm{C} ; \delta_{\mathrm{H}}\left(400 \mathrm{MHz}, \mathrm{DMSO}-d_{6}\right) 7.50(2 \mathrm{H}, \mathrm{s}$, exchange with $\left.\mathrm{D}_{2} \mathrm{O}, \mathrm{SO}_{2} \mathrm{NH}_{2}\right), 7.55(4 \mathrm{H}, \mathrm{m}), 7.67(2 \mathrm{H}, \mathrm{m}), 7.93$ $(1 \mathrm{H}, \mathrm{d}, J$ J 72$), 8.33(1 \mathrm{H}, \mathrm{s}), 13.16\left(1 \mathrm{H}, \mathrm{s}\right.$, exchange with $\left.\mathrm{D}_{2} \mathrm{O}, \mathrm{SH}\right)$; $\delta_{\mathrm{C}}\left(100 \mathrm{MHz}, \mathrm{DMSO}-d_{6}\right) 119.7,120.6,122.3,122.9,125.1,127.3$, $129.2,129.4,134.1,134.7,140.2,147.5,160.2,176.9 ; \mathrm{m} / z$ (ESI negative) $332.0[\mathrm{M}-\mathrm{H}]^{-}$.

Synthesis of 3-(6-chloro-2-mercapto-4-oxoquinazolin-3(4H)yl)benzenesulfonamide (3b). The titled compound $\mathbf{3 b}$ was obtained according to the general procedure previously reported using 2amino-5-chlorobenzoic acid $\mathbf{1 b}$ and 2-isothiocyanato-benzenesulfonamide 2. $88 \%$ yield, $\mathrm{mp}<300{ }^{\circ} \mathrm{C} ; \delta_{\mathrm{H}}\left(400 \mathrm{MHz}\right.$, DMSO- $\left.d_{6}\right) 7.42$ $\left(2 \mathrm{H}, \mathrm{s}\right.$, exchange with $\left.\mathrm{D}_{2} \mathrm{O}, \mathrm{SO}_{2} \mathrm{NH}_{2}\right), 7.58(3 \mathrm{H}, \mathrm{m}), 7.94(2 \mathrm{H}, \mathrm{m})$, $8.11(1 \mathrm{H}, \mathrm{s}), 8.38(1 \mathrm{H}, \mathrm{s}), 13.17\left(1 \mathrm{H}, \mathrm{s}\right.$, exchange with $\left.\mathrm{D}_{2} \mathrm{O}, \mathrm{SH}\right)$; $\delta_{\mathrm{C}}\left(100 \mathrm{MHz}, \mathrm{DMSO}-d_{6}\right) 119.6,121.1,125.2,126.3,127.2,128.2$, $129.3,130.4,133.6,136.5,140.4,140.5,160.6,176.9 ; \mathrm{m} / \mathrm{z}$ (ESI negative) $366.0[\mathrm{M}-\mathrm{H}]^{-}$.

Synthesis of 3-(7-chloro-2-mercapto-4-oxoquinazolin-3(4H)yl)benzenesulfonamide (3c). The titled compound $3 \mathbf{c}$ was obtained according to the general procedure previously reported using 2amino-4-chlorobenzoic acid 1c and 2-isothiocyanato-benzenesulfonamide 2. $69 \%$ yield; mp $191^{\circ} \mathrm{C} ; \delta_{\mathrm{H}}\left(400 \mathrm{MHz}, \mathrm{DMSO}-d_{6}\right) 7.43$ $\left(2 \mathrm{H}, \mathrm{s}\right.$, exchange with $\left.\mathrm{D}_{2} \mathrm{O}, \mathrm{SO}_{2} \mathrm{NH}_{2}\right), 7.50(7 \mathrm{H}, \mathrm{m}), 11.34(1 \mathrm{H}, \mathrm{s}$, exchange with $\left.\mathrm{D}_{2} \mathrm{O}, \mathrm{SH}\right) ; \delta_{\mathrm{C}}\left(100 \mathrm{MHz}, \mathrm{DMSO}-d_{6}\right) 119.0,119.5$, $122.8,123.0,126.8,127.3,132.2,133.5,133.6,138.4,140.0$, 148.8, 160.0, 177.5; $\mathrm{m} / \mathrm{z}$ (ESI positive) $368.00[\mathrm{M}+\mathrm{H}]^{+}$.

Synthesis of 3-(8-chloro-2-mercapto-4-oxoquinazolin-3(4H)yl)benzenesulfonamide (3d). The titled compound 3d was obtained according to the general procedure previously reported using 2-amino-3-chlorobenzoic acid 1d and 2-isothiocyanato-benzenesulfonamide $2.69 \%$ yield, $\mathrm{mp}<300{ }^{\circ} \mathrm{C} ; \delta_{\mathrm{H}}\left(400 \mathrm{MHz}\right.$, DMSO- $\left.d_{6}\right)$ $7.50\left(2 \mathrm{H}, \mathrm{s}\right.$, exchange with $\left.\mathrm{D}_{2} \mathrm{O}, \mathrm{SO}_{2} \mathrm{NH}_{2}\right), 7.62(3 \mathrm{H}, \mathrm{m}), 7.93(3 \mathrm{H}$, $\mathrm{m}), 8.03(1 \mathrm{H}, \mathrm{s}), 13.01\left(1 \mathrm{H}, \mathrm{s}\right.$, exchange with $\left.\mathrm{D}_{2} \mathrm{O}, \mathrm{SH}\right) ; \delta_{\mathrm{C}}$ $\left(100 \mathrm{MHz}, \mathrm{DMSO}-d_{6}\right) 119.4,121.8,125.7,126.5,127.2,127.5$, $130.6,133.5,136.5,137.7,140.6,146.0,160.1,177.4$; $\mathrm{m} / \mathrm{z}$ (ESI negative) $366.0[\mathrm{M}-\mathrm{H}]^{-}$.

Synthesis of 3-(7-bromo-2-mercapto-4-oxoquinazolin-3(4H)yl)benzenesulfonamide (3e). The titled compound $\mathbf{3 e}$ was obtained according to the general procedure previously reported using 2amino-4-bromobenzoic acid $\mathbf{1 e}$ and 2-isothiocyanato-benzenesulfonamide 2. $62 \%$ yield, $\mathrm{mp}<300{ }^{\circ} \mathrm{C} ; \delta_{\mathrm{H}}\left(400 \mathrm{MHz}\right.$, DMSO- $\left.d_{6}\right) 7.48$ $\left(2 \mathrm{H}, \mathrm{s}\right.$, exchange with $\left.\mathrm{D}_{2} \mathrm{O}, \mathrm{SO}_{2} \mathrm{NH}_{2}\right), 7.56(4 \mathrm{H}, \mathrm{m}), 7.87(1 \mathrm{H}, \mathrm{d}, J$ 7.1), $7.93(2 \mathrm{H}, \mathrm{m}), 13.16\left(1 \mathrm{H}, \mathrm{s}\right.$, exchange with $\left.\mathrm{D}_{2} \mathrm{O}, \mathrm{SH}\right) ; \delta_{\mathrm{c}}$ $\left(100 \mathrm{MHz}\right.$, DMSO- $\left.d_{6}\right) 111.5,117.3,124.9,127.1,128.6,129.7$, $130.1,130.9,135.5,140.8,142.6,143.9,159.4,177.1 ; \mathrm{m} / \mathrm{z}$ (ESI negative) $409.9[\mathrm{M}-\mathrm{H}]^{-}$.

Synthesis of 3-(8-bromo-2-mercapto-4-oxoquinazolin-3(4H)yl)benzenesulfonamide (3f). The titled compound $3 \mathbf{f}$ was obtained according to the general procedure previously reported using 2amino-3-bromobenzoic acid $\mathbf{1 f}$ and 2-isothiocyanato-benzenesulfonamide 2. $62 \%$ yield; mp $285^{\circ} \mathrm{C} ; \delta_{\mathrm{H}}\left(400 \mathrm{MHz}\right.$, DMSO- $\left.d_{6}\right) 7.43$ $\left(2 \mathrm{H}, \mathrm{s}\right.$, exchange with $\left.\mathrm{D}_{2} \mathrm{O}, \mathrm{SO}_{2} \mathrm{NH}_{2}\right), 7.60(7 \mathrm{H}, \mathrm{m}), 13.17(1 \mathrm{H}, \mathrm{s}$, exchange with $\left.\mathrm{D}_{2} \mathrm{O}, \mathrm{SH}\right) ; \delta_{\mathrm{C}}\left(100 \mathrm{MHz}\right.$, DMSO- $\left.d_{6}\right)$ 110.0, 120.1, $122.5,122.7,124.2,127.3,127.8,130.8,132.5,134.4,140.4$, 149.9, 159.9, 177.4; $\mathrm{m} / z$ (ESI positive) $411.9[\mathrm{M}+\mathrm{H}]^{+}$.
Synthesis of 3-(6-iodo-2-mercapto-4-oxoquinazolin-3(4H)-yl) benzenesulfonamide (3g). The titled compound $\mathbf{3 g}$ was obtained according to the general procedure previously reported using 2amino-5-iodobenzoic acid $\mathbf{1 g}$ and 2-isothiocyanato-benzenesulfonamide $2.82 \%$ yield, $\mathrm{mp}<300^{\circ} \mathrm{C} ; \delta_{\mathrm{H}}\left(400 \mathrm{MHz}\right.$, DMSO- $\left.d_{6}\right) 7.19$ $(2 \mathrm{H}, \mathrm{m}), 7.42(1 \mathrm{H}, \mathrm{d}, J$ 7.3), $7.46(1 \mathrm{H}, \mathrm{d}, J 7.2), 7.51(1 \mathrm{H}, \mathrm{m}), 7.55$ $\left(2 \mathrm{H}, \mathrm{s}\right.$, exchange with $\left.\mathrm{D}_{2} \mathrm{O}, \mathrm{SO}_{2} \mathrm{NH}_{2}\right), 8.15(1 \mathrm{H}, \mathrm{d}, J 7.3), 8.32(1 \mathrm{H}$, d, J 7.2), $13.25\left(1 \mathrm{H}, \mathrm{s}\right.$, exchange with $\left.\mathrm{D}_{2} \mathrm{O}, \mathrm{SH}\right) ; \delta_{\mathrm{C}}(100 \mathrm{MHz}$, DMSO-d ${ }_{6}$ ) 92.8, 119.6, 122.5, 123.8, 126.2, 128.1, 129.4, 134.1, 137.8, 141.3, 143.6, 147.3, 160.4, 177.2; $\mathrm{m} / z$ (ESI negative) 457.9 $[\mathrm{M}-\mathrm{H}]^{-}$.

Synthesis of 3-(6-fluoro-2-mercapto-4-oxo-4H-quinazolin-3yl)-benzenesulfonamide (3h). The titled compound $\mathbf{3 h}$ was obtained according to the general procedure previously reported using 2-amino-5-fluorobenzoic acid $\mathbf{1 h}$ and 2-isothiocyanato-benzenesulfonamide $2.53 \%$ yield, $\mathrm{mp}<300{ }^{\circ} \mathrm{C} ; \delta_{\mathrm{H}}\left(400 \mathrm{MHz}\right.$, DMSO- $\left.d_{6}\right)$ $7.38(3 \mathrm{H}, \mathrm{m}), 7.54\left(2 \mathrm{H}, \mathrm{s}\right.$, exchange with $\left.\mathrm{D}_{2} \mathrm{O}, \mathrm{SO}_{2} \mathrm{NH}_{2}\right), 7.96(2 \mathrm{H}$, $\mathrm{m}), 8.17(1 \mathrm{H}, \mathrm{s}), 8.33(1 \mathrm{H}, \mathrm{s}), 13.19\left(1 \mathrm{H}, \mathrm{s}\right.$, exchange with $\mathrm{D}_{2} \mathrm{O}$, $\mathrm{SH}) ; \quad \delta_{\mathrm{F}}\left(376 \mathrm{MHz}, \mathrm{DMSO}-d_{6}\right)-116.35(1 \mathrm{~F}, \mathrm{~s}) ; \delta_{\mathrm{C}}(100 \mathrm{MHz}$, DMSO- $\left.d_{6}\right) 113.5$ (d, $\left.{ }^{2} J_{\mathrm{C}-\mathrm{F}} 24\right), 117.9$ (d, $\left.{ }^{3} J_{\mathrm{C}-\mathrm{F}} 8\right), 119.6$ (d, $\left.{ }^{3} J_{\mathrm{C}-\mathrm{F}} 8\right)$, 124.5 (d, $\left.{ }^{2} J_{\text {C-F }} 24\right), 125.3,129.8,133.6,138.2,140.4,143.5,159.4$ (d, ${ }^{1} J_{\mathrm{C}-\mathrm{F}} 273$ ), 159.8 (d, ${ }^{4} J_{\mathrm{C}-\mathrm{F}} 3$ ), 161.5, 177.1; m/z (ESI negative) $350.0[\mathrm{M}-\mathrm{H}]^{-}$.

Synthesis of 3-(7-fluoro-2-mercapto-4-oxo-4H-quinazolin-3yl)-benzenesulfonamide ( $\mathbf{3 i}$ ). The titled compound $\mathbf{3 i}$ was obtained according to the general procedure previously reported using 2amino-4-fluorobenzoic acid $\mathbf{1 i}$ and 2-isothiocyanato-benzenesulfonamide 2. $58 \%$ yield, $\mathrm{mp}<300^{\circ} \mathrm{C}$; $\delta_{\mathrm{H}}\left(400 \mathrm{MHz}, \mathrm{DMSO}-d_{6}\right) 7.23$ $(2 \mathrm{H}, \mathrm{m}), 7.55\left(2 \mathrm{H}, \mathrm{s}\right.$, exchange with $\left.\mathrm{D}_{2} \mathrm{O}, \mathrm{SO}_{2} \mathrm{NH}_{2}\right), 7.96-8.01(4 \mathrm{H}$, $\mathrm{m}), 8.27(1 \mathrm{H}, \mathrm{s}), 13.18\left(1 \mathrm{H}, \mathrm{s}\right.$, exchange with $\left.\mathrm{D}_{2} \mathrm{O}, \mathrm{SH}\right) ; \delta_{\mathrm{F}}$ $\left(376 \mathrm{MHz}, \mathrm{DMSO}-d_{6}\right)-101.78(1 \mathrm{~F}, \mathrm{~s}) ; \delta_{\mathrm{C}}\left(100 \mathrm{MHz}, \mathrm{DMSO}-d_{6}\right)$ 107.3 (d, $\left.{ }^{2} J_{\text {C-F }} 26\right), 114.7$ (d, $\left.{ }^{2} J_{\text {C-F }} 13\right), 116.5,119.4,123.1,125.0$, 129.4, 130.3, 133.9, 142.3 (d, $\left.{ }^{3} J_{\text {C-F }} 13\right), 145.5$ (d, $\left.{ }^{2} J_{C-F} 26\right), 159.6$ (d, ${ }^{1} J_{\mathrm{C}-\mathrm{F}} 273$ ), $162.1,176.7 ; \mathrm{m} / \mathrm{z}$ (ESI negative) $350.0[\mathrm{M}-\mathrm{H}]^{-}$.

Synthesis of 3-(2-mercapto-6-methyl-4-oxo-4H-quinazolin-3$\mathrm{yl}$ )-benzenesulfonamide ( $\mathbf{3 j}$ ). The titled compound $\mathbf{3 j}$ was obtained according to the general procedure previously reported using 2amino-5-methylbenzoic acid $\mathbf{1 j}$ and 2-isothiocyanato-benzenesulfonamide 2. $62 \%$ yield, $\mathrm{mp}<300{ }^{\circ} \mathrm{C}$; $\delta_{\mathrm{H}}\left(400 \mathrm{MHz}\right.$, DMSO- $\left.d_{6}\right) 2.44$ $(3 \mathrm{H}, \mathrm{s}), 7.23(2 \mathrm{H}, \mathrm{m}), 7.55\left(2 \mathrm{H}, \mathrm{s}\right.$, exchange with $\left.\mathrm{D}_{2} \mathrm{O}, \mathrm{SO}_{2} \mathrm{NH}_{2}\right)$, $7.87(3 \mathrm{H}, \mathrm{m}), 7.94(2 \mathrm{H}, \mathrm{m}), 13.13\left(1 \mathrm{H}, \mathrm{s}\right.$, exchange with $\left.\mathrm{D}_{2} \mathrm{O}, \mathrm{SH}\right)$; $\delta_{\mathrm{C}}\left(100 \mathrm{MHz}, \mathrm{DMSO}-d_{6}\right) 22.9,119.5,120.7,122.2,123.1,125.0$, $129.3,129.8,133.5,134.3,137.5,140.4,144.6,159.3,177.1 ; \mathrm{m} / \mathrm{z}$ (ESI negative) $346.0[\mathrm{M}-\mathrm{H}]^{-}$.

Synthesis of 3-(2-mercapto-8-methyl-4-oxoquinazolin-3(4H)yl)benzenesulfonamide (3k). The titled compound $\mathbf{3 k}$ was obtained according to the general procedure previously reported using 2-amino-3-methylbenzoic acid 1k and 2-isothiocyanatobenzenesulfonamide 2 . $63 \%$ yield, $\mathrm{mp}<300{ }^{\circ} \mathrm{C}$; $\delta_{\mathrm{H}}(400 \mathrm{MHz}$, DMSO- $\left.d_{6}\right) 2.42(3 \mathrm{H}, \mathrm{s}), 7.25(2 \mathrm{H}, \mathrm{m}), 7.55\left(2 \mathrm{H}, \mathrm{s}, \mathrm{D}_{2} \mathrm{O}\right.$ exchangeable, $\left.\mathrm{SO}_{2} \mathrm{NH}_{2}\right), 7.78(3 \mathrm{H}, \mathrm{m}), 7.97(2 \mathrm{H}, \mathrm{m}), 13.03(1 \mathrm{H}, \mathrm{s}$, exchange with $\left.\mathrm{D}_{2} \mathrm{O}, \mathrm{SH}\right) ; \delta_{\mathrm{C}}\left(100 \mathrm{MHz}, \mathrm{DMSO}-d_{6}\right) 23.0,118.9,121.1,123.4$, $125.3,126.3,127.8,129.5,130.9,132.3,133.0,139.1,140.7$, 159.2, 176.5; $\mathrm{m} / \mathrm{z}$ (ESI negative) $346.0[\mathrm{M}-\mathrm{H}]^{-}$.

Synthesis of 3-(2-mercapto-6,7-dimethyl-4-oxoquinazolin-3 (4H)-yl)benzenesulfonamide (31). The titled compound 31 was obtained according to the general procedure previously reported using 2-amino-4,5-dimethylbenzoic acid $\mathbf{1 1}$ and 2-isothiocyanatobenzenesulfonamide 2 . $68 \%$ yield, $\mathrm{mp}<300{ }^{\circ} \mathrm{C}$; $\delta_{\mathrm{H}}(400 \mathrm{MHz}$, DMSO-d $\left.d_{6}\right) 2.85(6 \mathrm{H}, \mathrm{s}), 6.84(1 \mathrm{H}, \mathrm{s}), 7.23(1 \mathrm{H}, \mathrm{s}), 7.56(2 \mathrm{H}, \mathrm{s}$, exchange with $\left.\mathrm{D}_{2} \mathrm{O}, \mathrm{SO}_{2} \mathrm{NH}_{2}\right), 7.91(4 \mathrm{H}, \mathrm{m}), 13.17(1 \mathrm{H}, \mathrm{s}$, exchange with $\left.\mathrm{D}_{2} \mathrm{O}, \mathrm{SH}\right) ; \delta_{\mathrm{C}}\left(100 \mathrm{MHz}\right.$, DMSO- $\left.d_{6}\right) 23.7,27.5,118.2,119.8$, $122.5,123.3,124.2,127.5,128.1,131.9,134.2,138.6,140.8$, 143.4, 159.6, 166.5; $\mathrm{m} / \mathrm{z}$ (ESI negative) $360.0[\mathrm{M}-\mathrm{H}]^{-}$.

Synthesis of 3-(2-mercapto-6-methoxy-4-oxoquinazolin-3 (4H)-yl)benzenesulfonamide ( $\mathbf{3 m}$ ). The titled compound $\mathbf{3 m}$ was 
obtained according to the general procedure previously reported using 2-amino-5-methoxybenzoic acid $\mathbf{1 m}$ and 2-isothiocyanatobenzenesulfonamide 2 . $71 \%$ yield; $\mathrm{mp}>300{ }^{\circ} \mathrm{C} ; \delta_{\mathrm{H}}(400 \mathrm{MHz}$, DMSO- $\left.d_{6}\right) 3.87(3 \mathrm{H}, \mathrm{s}), 7.40(1 \mathrm{H}, \mathrm{s}), 7.48(2 \mathrm{H}, \mathrm{s}$, exchange with $\left.\mathrm{D}_{2} \mathrm{O}, \mathrm{SO}_{2} \mathrm{NH}_{2}\right), 7.54(2 \mathrm{H}, \mathrm{s}), 7.59(1 \mathrm{H}, \mathrm{m}), 7.73(1 \mathrm{H}, \mathrm{m}), 7.78(1 \mathrm{H}$, s), $7.91(1 \mathrm{H}, \mathrm{d}, J 2.0), 13.12\left(1 \mathrm{H}, \mathrm{s}\right.$, exchange with $\left.\mathrm{D}_{2} \mathrm{O}, \mathrm{SH}\right) ; \delta_{\mathrm{C}}$ $\left(100 \mathrm{MHz}\right.$, DMSO- $\left.d_{6}\right)$ 57.8, 105.0, 118.7, 120.0, 120.2, 123.0, $127.2,128.3,131.6,131.8,138.7,140.0 ; 158.8,160.6,177.8 ; \mathrm{m} / \mathrm{z}$ (ESI negative) $362.0[\mathrm{M}-\mathrm{H}]^{-}$.

Synthesis of 3-(2-mercapto-7-methoxy-4-oxoquinazolin-3 (4H)-yl)benzenesulfonamide (3n). The titled compound $\mathbf{3 n}$ was obtained according to the general procedure previously reported using 2-amino-4-methoxybenzoic acid $\mathbf{1 n}$ and 2-isothiocyanatobenzenesulfonamide 2. $71 \%$ yield; $\mathrm{mp} 297^{\circ} \mathrm{C} ; \delta_{\mathrm{H}}(400 \mathrm{MHz}$, DMSO-d $\left.d_{6}\right) 3.90(3 \mathrm{H}, \mathrm{s}), 6.95(1 \mathrm{H}, \mathrm{s}) 7.20(1 \mathrm{H}, \mathrm{t}, J 7.2), 7.42(2 \mathrm{H}, \mathrm{s}$, exchange with $\left.\mathrm{D}_{2} \mathrm{O}, \mathrm{OH}\right), 7.65-7.75(3 \mathrm{H}, \mathrm{m}), 8.05(2 \mathrm{H}, \mathrm{m}), 13.10$ $\left(1 \mathrm{H}, \mathrm{s}\right.$, exchange with $\left.\mathrm{D}_{2} \mathrm{O}, \mathrm{SH}\right) ; \delta_{\mathrm{C}}\left(100 \mathrm{MHz}\right.$, DMSO- $\left.d_{6}\right) 57.8$, $106.8,114.2,115.3,120.1,123.1,125.8,130.3,133.2,133.3$, 140.0, 146.6, 160.0, 163.2, 172.5; $\mathrm{m} / \mathrm{z}$ (ESI positive) $364.0[\mathrm{M}+\mathrm{H}]^{+}$.

Synthesis of 3-(2-mercapto-8-methoxy-4-oxoquinazolin-3 (4H)-yl)benzenesulfonamide (3o). The titled compound 30 was obtained according to the general procedure previously reported using 2-amino-3-methoxybenzoic acid $\mathbf{1 0}$ and 2-isothiocyanatobenzenesulfonamide 2 . $62 \%$ yield, $\mathrm{mp}<300{ }^{\circ} \mathrm{C}$; $\delta_{\mathrm{H}}(400 \mathrm{MHz}$, DMSO- $\left.d_{6}\right) 3.94(3 \mathrm{H}, \mathrm{s}), 7.00(2 \mathrm{H}, \mathrm{m}), 7.54(2 \mathrm{H}, \mathrm{s}$, exchange with $\left.\mathrm{D}_{2} \mathrm{O}, \mathrm{SO}_{2} \mathrm{NH}_{2}\right), 7.77(3 \mathrm{H}, \mathrm{m}), 7.94(2 \mathrm{H}, \mathrm{m}), 12.54(1 \mathrm{H}, \mathrm{s}$, exchange with $\left.\mathrm{D}_{2} \mathrm{O}, \mathrm{SH}\right) ; \delta_{\mathrm{C}}\left(100 \mathrm{MHz}\right.$, DMSO- $\left.d_{6}\right) 57.1,119.2,119.9,121.1$, $121.7,122.9,124.3,125.7,127.5,128.4,132.2,139.0,151.2$, 159.7, 176.7; $\mathrm{m} / \mathrm{z}$ (ESI negative) $362.0[\mathrm{M}-\mathrm{H}]^{-}$.

Synthesis of 3-(2-mercapto-6,7-dimethoxy-4-oxoquinazolin-3 (4H)-yl)benzenesulfonamide (3p). The titled compound $\mathbf{3 p}$ was obtained according to the general procedure previously reported using 2-amino-4,5-dimethoxybenzoic acid $\mathbf{1 p}$ and 2-isothiocyanato-benzenesulfonamide 2. $80 \%$ yield, $\mathrm{mp}<300^{\circ} \mathrm{C} ; \delta_{\mathrm{H}}$ (400 MHz, DMSO-d $\left.d_{6}\right) 3.86(3 \mathrm{H}, \mathrm{s}), 3.92(3 \mathrm{H}, \mathrm{s}), 6.85(1 \mathrm{H}, \mathrm{s}), 7.33$ $(1 \mathrm{H}, \mathrm{s}), 7.55\left(2 \mathrm{H}, \mathrm{s}\right.$, exchange with $\left.\mathrm{D}_{2} \mathrm{O}, \mathrm{SO}_{2} \mathrm{NH}_{2}\right), 7.97(4 \mathrm{H}, \mathrm{m})$, $13.02\left(1 \mathrm{H}, \mathrm{s}\right.$, exchange with $\left.\mathrm{D}_{2} \mathrm{O}, \mathrm{SH}\right) ; \delta_{\mathrm{C}}\left(100 \mathrm{MHz}, \mathrm{DMSO}-d_{6}\right)$ 56.8, 56.9, 99.0, 108.0, 109.5, 126.2, 127.3, 130.4, 133.6, 136.5, 144.5, 145.9, 147.6, 156.4, 160.2, 175.6; $\mathrm{m} / \mathrm{z}$ (ESI negative) 392.0 $[\mathrm{M}-\mathrm{H}]^{-}$.

Synthesis of 3-(2-mercapto-6,7,8-trimethoxy-4-oxoquinazolin3(4H)-yl)benzenesulfonamide (3q). The titled compound $\mathbf{3 q}$ was obtained according to the general procedure previously reported using 2-amino-3,4,5-trimethoxybenzoic acid $\mathbf{1 q}$ and 2-isothiocyanato-benzenesulfonamide $2.75 \%$ yield, $\mathrm{mp}<300{ }^{\circ} \mathrm{C} ; \delta_{\mathrm{H}}$ (400 MHz, DMSO-d $\left.d_{6}\right) 3.91$ (3H, s), 3.95 (3H, s), $3.96(3 \mathrm{H}, \mathrm{s}), 7.25$ $(1 \mathrm{H}, \mathrm{s}), 7.55\left(3 \mathrm{H}, \mathrm{m}, 2 \mathrm{H}\right.$ exchange with $\left.\mathrm{D}_{2} \mathrm{O} \mathrm{SO} \mathrm{SO}_{2} \mathrm{NH}_{2}\right), 7.73(2 \mathrm{H}$, m), $7.90(1 \mathrm{H}, \mathrm{d}, J 8), 12.36\left(1 \mathrm{H}, \mathrm{s}\right.$, exchange with $\left.\mathrm{D}_{2} \mathrm{O}, \mathrm{SH}\right) ; \delta_{\mathrm{C}}$ $\left(100 \mathrm{MHz}, \mathrm{DMSO}-d_{6}\right) 57.1,61.8,62.6,104.2,112.5,126.3,127.2$, $130.0,130.6,133.6,140.6,140.9,145.9,148.6,151.3,160.1$, 175.9; $\mathrm{m} / \mathrm{z}$ (ESI negative) $422.0[\mathrm{M}-\mathrm{H}]^{-}$.

\subsection{CA inhibition}

An Applied Photophysics stopped-flow instrument has been used for assaying the $\mathrm{CA}$ catalyzed $\mathrm{CO}_{2}$ hydration activity. ${ }^{27}$ Phenol red (at a concentration of $0.2 \mathrm{mM}$ ) has been used as indicator, working at the absorbance maximum of $557 \mathrm{~nm}$, with $20 \mathrm{mM}$ Hepes ( $\mathrm{pH}$ 7.5 ) as buffer, and $20 \mathrm{mM} \mathrm{Na}_{2} \mathrm{SO}_{4}$ (for maintaining constant the ionic strength), following the initial rates of the CA-catalyzed $\mathrm{CO}_{2}$ hydration reaction for a period of $10-100 \mathrm{~s}$. The $\mathrm{CO}_{2}$ concentrations ranged from 1.7 to $17 \mathrm{mM}$ for the determination of the kinetic parameters and inhibition constants. For each inhibitor at least six traces of the initial $5-10 \%$ of the reaction have been used for determining the initial velocity. The uncatalyzed rates were determined in the same manner and subtracted from the total observed rates.
Stock solutions of inhibitor $(0.1 \mathrm{mM})$ were prepared in distilleddeionized water and dilutions up to $0.01 \mathrm{nM}$ were done thereafter with the assay buffer. Inhibitor and enzyme solutions were preincubated together for $15 \mathrm{~min}-6 \mathrm{~h}$ at room temperature prior to assay, in order to allow for the formation of the E-I complex. Data from Table 1 were obtained after 15 min incubation of enzyme and inhibitor. The inhibition constants were obtained by non-linear leastsquares methods using PRISM 3 and the Cheng-Prusoff equation, as reported earlier, ${ }^{29,30}$ and represent the mean from at least three different determinations. All CA isoforms were recombinant ones obtained in-house as reported earlier. ${ }^{30}$

\section{Acknowledgments}

The authors are grateful to Dr. Mariangela Ceruso of the Università degli Studi di Firenze for helpful discussion and execution of the in vitro enzymatic experiments. This research was financed by two EU grants of the seventh framework program (Metoxia and Dynano projects to C.T.S.). This project was supported by the National Plan of Science, Technology and Innovation (Grant No. 12-MED2980-54), Prince Sattam bin Abdulaziz University, Alkharj, PO Box 173, 11942 to A.M.A and F.C.

\section{References}

1. (a) Supuran CT. Nat Rev Drug Disc. 2008;7:168;

(b) Neri D, Supuran CT. Nat Rev Drug Disc. 2011;10:767;

(c) Supuran CT. Future Med Chem. 2011;3:1165;

(d) Supuran CT. Bioorg Med Chem. 2013;21:1377.

2. https://clinicaltrials.gov/ct2/show/NCT02215850.

3. Carrasco-Triguero M, Yi JH, Dere R, et al. Bioanalysis. 2013;5:1007.

4. Borsi L, Balza E, Bestagno M, et al. Int J Cancer. 2002;102:75.

5. Dennis MS, Jin HK, Dugger D, et al. Cancer Res. 2007;67:254.

6. (a) Krall N, Scheuermann J, Neri D. Angew Chem. 2013;125:1424;

(b) Krall N, Scheuermann J, Neri D. Angew Chem Int Ed Engl. 2013;52:1384.

7. (a) Davis RA, Vullo D, Maresca A, Supuran CT, Poulsen SA. Bioorg Med Chem. 2013;21:1539;

(b) Carreyre H, Coustard JM, Carre G, et al. Bioorg Med Chem. 2013;21:3790; (c) Ekinci D, Kurbanoglu NI, Salamci E, Senturk M, Supuran CT. J Enzyme Inhib Med Chem. 2012;27:845;

(d) Ekinci D, Karagoz L, Ekinci D, Senturk M, Supuran CT. J Enzyme Inhib Med Chem. 2013;28:283.

8. (a) Scozzafava A, Passaponti M, Supuran CT, Gülçin İ. J Enzyme Inhib Med Chem. 2015;30:586;

(b) Koz O, Ekinci D, Perrone A, et al. J Enzyme Inhib Med Chem. 2013;28:412; (c) Maresca A, Akyuz G, Osman SM, AlOthman Z, Supuran CT. Bioorg Med Chem. 2015;23:7181;

(d) Supuran CT. Mol Divers.. 2011;15:305;

(e) Karioti A, Carta F, Supuran CT. Molecules. 2016;21:1649;

(f) Karioti A, Ceruso M, Carta F, Bilia AR, Supuran CT. Bioorg Med Chem. 2015;23:7219.

9. (a) Davis RA, Vullo D, Supuran CT, Poulsen SA. Biomed Res Int. 2014;374079; (b) Carta F, Temperini C, Innocenti A, Scozzafava A, Kaila K, Supuran CT. J Med Chem. 2010;53:5511.

10. (a) Alp C, Maresca A, Alp NA, et al. J Enzyme Inhib Med Chem. 2013;28:294; (b) Carradori S, Secci D, De Monte C, et al. Bioorg Med Chem. 2016;1095:24; (c) Ivanova J, Leitans J, Tanc M, et al. Chem Commun (Camb). 2015:51:7108; (d) Moeker J, Peat TS, Bornaghi LF, Vullo D, Supuran CT, Poulsen SA. J Med Chem. 2014; 7:3522;

(e) D'Ascenzio M, Carradori S, De Monte C, Secci D, Ceruso M, Supuran CT. Bioorg Med Chem. 1821;2014:22;

(f) Métayer B, Mingot A, Vullo D, Supuran CT, Thibaudeau S. Chem Commun (Camb). 2013;49:6015.

11. (a) Vullo D, Durante M, Di Leva FS, et al. J Med Chem. 2016;59:5857;

(b) Bozdag M, Carta F, Vullo D, et al. Bioorg Med Chem. 2015;23:2368;

(c) Carta F, Aggarwal M, Maresca A, et al. J Med Chem. 2012;55:1721;

(d) Carta F, Aggarwal M, Maresca A, Scozzafava A, McKenna R, Supuran CT. Chem Commun. 1868;2012:48.

12. Carta F, Akdemir A, Scozzafava A, Masini E, Supuran CT. J Med Chem. 2013;56:4691.

13. (a) Maresca A, Temperini C, Pochet L, Masereel B, Scozzafava A, Supuran CT. J Med Chem. 2010;53:335;

(b) Abellán-Flos M, Tanç M, Supuran CT, Vincent SP. Org Biomol Chem. 2015:13:7445.

14. (a) Maresca A, Supuran CT. Bioorg Med Chem Lett. 2010;20:4511;

(b) Maresca A, Scozzafava A, Supuran CT. Bioorg Med Chem Lett. 2010;20:7255; (c) Bozdag M, Ferraroni M, Carta F, et al. J Med Chem. 2014;57:9152. 
15. (a) Touisni N, Maresca A, McDonald PC, et al. J Med Chem. 2011;54:8271;

(b) Bonneau A, Maresca A, Winum JY, Supuran CT. J Enzyme Inhib Med Chem. 2013;28:397;

(c) Sharma A, Tiwari M, Supuran CT. J Enzyme Inhib Med Chem. 2014;29:292.

16. (a) Carta F, Maresca A, Scozzafava A, Supuran CT. Bioorg Med Chem Lett. 2012;22:267;

(b) Carta F, Maresca A, Scozzafava A, Supuran CT. Bioorg Med Chem. 2012;20:2266;

(c) Carta F, Vullo D, Maresca A, Scozzafava A, Supuran CT. Bioorg Med Chem Lett. 2012;22:2182.

17. (a) Tanc M, Carta F, Bozdag M, Scozzafava A, Supuran CT. Bioorg Med Chem. 2013;15:4502;

(b) Grandane A, Tanc M, Zalubovskis R, Supuran CT. Bioorg Med Chem Lett. 2014;5:1256;

(c) Grandane A, Tanc M, Zalubovskis R, Supuran CT. Bioorg Med Chem. 2014:5:1522;

(d) Tars K, Vullo D, Kazaks A, et al. J Med Chem. 2013;56:293.

18. (a) Tanc M, Carta F, Scozzafava A, Supuran CT. Org Biomol Chem. 2015;13:77;

(b) Grandane A, Tanc M, Di Cesare Mannelli L, et al. J Med Chem. 2015;58:3975.

19. (a) Supuran CT. Biochem J. 2016;473:2023;

(b) Mahon BP, Bhatt A, Socorro L, et al. Biochemistry. 2016;55:4642;

(c) Alterio V, Di Fiore A, D’Ambrosio K, Supuran CT, De Simone G. Chem Rev. 2012;112:4421.
20. Carta F, Supuran CT, Scozzafava A. Future Med Chem. 2014;6:1149.

21. (a) Nocentini A, Carta F, Ceruso M, Bartolucci G, Supuran CT. Bioorg Med Chem. 2015;23:6955

22. (a) Nocentini A, Ceruso M, Carta F, Supuran CT. J Enzyme Inhib Med Chem. 2016;31:1226.

23. Avram S, Milac AL, Carta F, Supuran CT. J Enzyme Inhib Med Chem. 2013;28:350

24. Alafeefy AM, Carta F, Ceruso M, Al-Tamimi AM, Al-Kahtani AA, Supuran CT Bioorg Med Chem. 2016;24:1402.

25. Bozdag M, Alafeefy AM, Carta F, et al. Bioorg Med Chem. 2016;24:4100.

26. Vullo D, Supuran CT, Scozzafava A, et al. Bioorg Med Chem. 2016;24:3643.

27. Khalifah RG. J Biol Chem. 1971;246:2561.

28. McKee RL, Bost RW. J Am Chem Soc. 1946;68:2506.

29. Casini A, Scozzafava A, Mincione F, Menabuoni L, Supuran CT. J Enzyme Inhib Med Chem. 2002;17:333.

30. (a) Lomelino CL, Mahon BP, McKenna R, Carta F, Supuran CT. Bioorg Med Chem. 2016;24:976;

(b) Bozdag M, Alafeefy AM, Altamimi AM, Vullo D, Carta F, Supuran CT. Bioorg Med Chem. 2017;25:677;

(c) Angeli A, Peat TS, Bartolucci G, Nocentini A, Supuran CT, Carta F. Org Biomol Chem. 2016:14:11353. 